\title{
W. B. Yeats, the Abbey Theatre, Censorship, and the Irish State: Adding the Half-Pence to the Pence
}

\section{Hélène Lecossois}

\section{(2) OpenEdition}

\section{Journals}

Electronic version

URL: https://journals.openedition.org/etudesirlandaises/3236

DOI: 10.4000/etudesirlandaises.3236

ISSN: 2259-8863

\section{Publisher}

Presses universitaires de Caen

\section{Printed version}

Date of publication: 30 October 2012

Number of pages: $176-177$

ISBN: 978-7535-2158-2

ISSN: 0183-973X

\section{Electronic reference}

Hélène Lecossois, "W. B. Yeats, the Abbey Theatre, Censorship, and the Irish State: Adding the HalfPence to the Pence", Études irlandaises [Online], 37-2 | 2012, Online since 30 October 2012, connection on 28 July 2022. URL: http://journals.openedition.org/etudesirlandaises/3236 ; DOI: https://doi.org/ 10.4000/etudesirlandaises.3236

This text was automatically generated on 28 July 2022

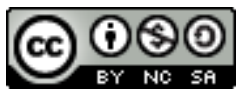

Creative Commons - Attribution-NonCommercial-ShareAlike 4.0 International - CC BY-NC-SA 4.0 https://creativecommons.org/licenses/by-nc-sa/4.0/ 


\title{
W. B. Yeats, the Abbey Theatre, Censorship, and the Irish State: Adding the Half-Pence to the Pence
}

\author{
Hélène Lecossois
}

\section{REFERENCES}

Lauren ARRINGTON, W. B. Yeats, the Abbey Theatre, Censorship, and the Irish State: Adding the Half-Pence to the Pence, Oxford, Oxford University Press, 2010, 210 p., ISBN

978-0-19-959057-5.

1 Impressively researched and clearly argued, Lauren Arrington's book makes a significant contribution to the study of early 20th century Abbey Theatre productions in relation to the wider political context of the period. It also sheds fascinating light on the crucial (and often ambivalent) involvement of W. B. Yeats in both the management of the Abbey Theatre and the politics of the Irish Free State.

2 Lauren Arrington's history of the Abbey theatre spans the period starting with what has come to be known as the Irish Revolution, 1916, and ending with the death of the last surviving founder of the Abbey Theatre, W. B. Yeats, in 1939. It comprises seven chapters, which follow a chronological order, a bibliography and an index.

3 Arrington's investigation challenges the widely accepted assumption that unlike England, the emerging Irish state did not censor its theatre. As there is no Irish equivalent to the Lord Chamberlain's records, in other words no documented history of Irish theatre censorship, Lauren Arrington turned to peripheral source material to reveal the elusive nature of theatre censorship in Ireland. The archival sources informing her argument include a rich and wide range of materials: financial records, government correspondence, minutes from the Abbey's directors' meetings, Dáil records, prompt copies of plays, playwrights' papers and correspondence, etc. 
4 If, as she puts it herself, "totting up pounds and shillings and adding the half-pence to the pence might be regarded as tedious - and perhaps soul-destroying - work by scholars accustomed to exploring the theoretical periphery of the well-trod territory of Irish National Theatre" (192), her book nonetheless succeeds in a rather engaging way in highlighting financial and political motivations lying behind some aesthetic choices and clarifying the active part played by Abbey directors in self-censoring plays whenever they saw potential financial gain - or in fuelling controversies when there was hope for publicity.

5 Lauren Arrington's book enhances our understanding of the cultural history of the period, placing special emphasis on the interaction between the Abbey directors and the State and in particular their negotiation to secure a subsidy that would ensure the future of the theatre. It underlines the material (financial) and ideological considerations which presided over the production of plays on the self-proclaimed national stage and radically questions W. B. Yeats's integrity in the process. Far from the champion of artistic freedom he often claimed to be, W. B. Yeats appears as a Machiavellian character who willingly sacrificed plays in order to protect the longevity of "his" theatre. The book is written in a fine and lucid style, which makes it not only a well-documented source of information which will undoubtedly prove useful for future research, but also a pleasant read.

\section{AUTHORS}

\section{HÉLÈNE LECOSSOIS}

Université du Maine 